\title{
Defense of Marriage Acts: A Fifty State Survey
}

Erica A. Holzer

William Mitchell College of Law

Follow this and additional works at: http://open.mitchellhamline.edu/stusch Part of the Constitutional Law Commons, and the Family Law Commons

\section{Recommended Citation}

Holzer, Erica A., "Defense of Marriage Acts: A Fifty State Survey" (2012). Student Scholarship. Paper 1.

http://open.mitchellhamline.edu/stusch/1 


\section{Defense of Marriage Acts: A Fifty State Survey \\ Updated January 31, 2012 \\ Erica A. Holzer}

This document includes every DoMA statute and constitutional amendment in all 50 states in alphabetical order as of January 31, 2012. The text of these laws is provided, as well as a link to the statute or constitutional amendment on Westlaw.

\section{Alabama \\ c AL ST \& 30-1-19 Marriage, recognition thereof, between persons of the same sex prohibited}

(a) This section shall be known and may be cited as the "Alabama Marriage Protection Act."

(b) Marriage is inherently a unique relationship between a man and a woman. As a matter of public policy, this state has a special interest in encouraging, supporting, and protecting the unique relationship in order to promote, among other goals, the stability and welfare of society and its children. A marriage contracted between individuals of the same sex is invalid in this state.

(c) Marriage is a sacred covenant, solemnized between a man and a woman, which, when the legal capacity and consent of both parties is present, establishes their relationship as husband and wife, and which is recognized by the state as a civil contract.

(d) No marriage license shall be issued in the State of Alabama to parties of the same sex.

(e) The State of Alabama shall not recognize as valid any marriage of parties of the same sex that occurred or was alleged to have occurred as a result of the law of any jurisdiction regardless of whether a marriage license was issued.

\section{Alaska \\ c $\underline{\text { AK CONST Art. } 1, \S 25}$ Marriage}

To be valid or recognized in this State, a marriage may exist only between one man and one woman.

C $\underline{\text { AK ST } \$ 25.05 .011 ~ C i v i l ~ c o n t r a c t ~}$

(a) Marriage is a civil contract entered into by one man and one woman that requires both a license and solemnization. The man and the woman must each be at least one of the following:

(1) 18 years of age or older and otherwise capable;

(2) qualified for a license under AS 25.05.171; or 
(3) a member of the armed forces of the United States while on active duty.

(b) A person may not be joined in marriage in this state until a license has been obtained for that purpose as provided in this chapter. A marriage performed in this state is not valid without solemnization as provided in this chapter.

c AK ST § 25.05.013 Same-sex marriages

(a) A marriage entered into by persons of the same sex, either under common law or under statute, that is recognized by another state or foreign jurisdiction is void in this state, and contractual rights granted by virtue of the marriage, including its termination, are unenforceable in this state.

(b) A same-sex relationship may not be recognized by the state as being entitled to the benefits of marriage.

\section{Arizona}

c $\underline{\text { AZ ST } \$ 25-101}$ Void and prohibited marriages

A. Marriage between parents and children, including grandparents and grandchildren of every degree, between brothers and sisters of the one-half as well as the whole blood, and between uncles and nieces, aunts and nephews and between first cousins, is prohibited and void.

B. Notwithstanding subsection A, first cousins may marry if both are sixty-five years of age or older or if one or both first cousins are under sixty-five years of age, upon approval of any superior court judge in the state if proof has been presented to the judge that one of the cousins is unable to reproduce.

C. Marriage between persons of the same sex is void and prohibited.

AZ ST $\S 25-103$ Purposes of title; application of title

A. It is declared that the public policy of this state and the general purposes of this title are:

1. To promote strong families;

2. To promote strong family values.

B. It also is the declared public policy of this state and the general purpose of this title that absent evidence to the contrary, it is in a child's best interest:

1. To have substantial, frequent, meaningful and continuing parenting time with both parents.

2. To have both parents participate in decision-making about the child.

C. A court shall apply the provisions of this title in a manner that is consistent with this section.

c AZ ST $\S 25-112$ Marriages contracted in another state; validity and effect 
A. Marriages valid by the laws of the place where contracted are valid in this state, except marriages that are void and prohibited by $\S 25-101$.

B. Marriages solemnized in another state or country by parties intending at the time to reside in this state shall have the same legal consequences and effect as if solemnized in this state, except marriages that are void and prohibited by $\S 25-101$.

C. Parties residing in this state may not evade the laws of this state relating to marriage by going to another state or country for solemnization of the marriage.

c $\underline{\text { AZ ST } \S 25-901}$ Covenant marriage; declaration of intent; filing requirements

A. Persons who have the legal capacity to marry pursuant to this title may enter into a covenant marriage by declaring their intent to do so on their application for a license obtained pursuant to $\S 25-121$ and by complying with the requirements of this chapter. The returned marriage license shall be recorded as provided by $\S 25-123$ with an indication that the marriage is a covenant marriage, and the declaration shall be filed by the clerk.

B. A declaration of intent to enter into a covenant marriage shall contain all of the following:

1. The following written statement:

\section{A Covenant Marriage}

We solemnly declare that marriage is a covenant between a man and a woman who agree to live together as husband and wife for as long as they both live. We have chosen each other carefully and have received premarital counseling on the nature, purposes and responsibilities of marriage. We understand that a covenant marriage is for life. If we experience marital difficulties, we commit ourselves to take all reasonable efforts to preserve our marriage, including marital counseling.

With full knowledge of what this commitment means, we do declare that our marriage will be bound by Arizona law on covenant marriages and we promise to love, honor and care for one another as husband and wife for the rest of our lives.

2. An affidavit by the parties that they have received premarital counseling from a member of the clergy or from a marriage counselor. Premarital counseling shall include a discussion of the seriousness of covenant marriage, communication of the fact that a covenant marriage is a commitment for life, a discussion of the obligation to seek marital counseling in times of marital difficulties and a discussion of the exclusive grounds for legally terminating a covenant marriage by dissolution of marriage or legal separation.

3. The signatures of both parties witnessed by a court clerk.

C. A notarized attestation that is signed by the clergy or counselor must be submitted with the application for a license and shall confirm that the parties were counseled as to the nature and purpose of the marriage and the grounds for its termination and that the counselor provided to the parties the informational pamphlet developed by the supreme court pursuant to this chapter. The clerk shall document that the attestation was submitted. 


\section{Arkansas}

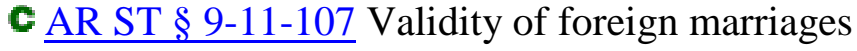

(a) All marriages contracted outside this state that would be valid by the laws of the state or country in which the marriages were consummated and in which the parties then actually resided shall be valid in all the courts in this state.

(b) This section shall not apply to a marriage between persons of the same sex.

c AR ST $\S 9-11-109$ Same sex marriage void

Marriage shall be only between a man and a woman. A marriage between persons of the same sex is void.

c AR ST \& 9-11-208 Licenses not issued to persons of the same sex--Minimum age requirements

(a)(1)(A) It is the public policy of the State of Arkansas to recognize the marital union only of man and woman.

(B) A license shall not be issued to a person to marry another person of the same sex, and no same-sex marriage shall be recognized as entitled to the benefits of marriage.

(2) Marriages between persons of the same sex are prohibited in this state. Any marriage entered into by a person of the same sex, when a marriage license is issued by another state or by a foreign jurisdiction, shall be void in Arkansas, and any contractual or other rights granted by virtue of that license, including its termination, shall be unenforceable in the Arkansas courts.

(3) However, nothing in this section shall prevent an employer from extending benefits to a person who is a domestic partner of an employee.

(b) A license shall not be issued to a person to marry unless and until the female shall attain the age of sixteen (16) years and the male the age of seventeen (17) years and then only by written consent by a parent or guardian until the male shall have attained the age of eighteen (18) years and the female the age of eighteen (18) years.

\section{$\underline{\text { AR CONST Amend. 83, } \$ 1}$ Marriage}

Marriage consists only of the union of one man and one woman.

\section{c $\underline{\text { AR CONST Amend. } 83, \S 2}$ Marital Status}

Legal status for unmarried persons which is identical or substantially similar to marital status shall not be valid or recognized in Arkansas, except that the legislature may recognize a common law marriage from another state between a man and a woman.

AR CONST Amend. 83, § 3 Capacity, rights, obligations, privileges, and immunities

The Legislature has the power to determine the capacity of persons to marry, subject to this amendment, and the legal rights, obligations, privileges, and immunities of marriage. 


\section{California}

PCA FAM \& 300 Consent; issuance of license and solemnization; marriage license and marriage certificate

(a) Marriage is a personal relation arising out of a civil contract between a man and a woman, to which the consent of the parties capable of making that contract is necessary. Consent alone does not constitute marriage. Consent must be followed by the issuance of a license and solemnization as authorized by this division, except as provided by $\underline{\text { Section }}$ $\underline{425}$ and Part 4 (commencing with Section 500).

(b) For purposes of this part, the document issued by the county clerk is a marriage license until it is registered with the county recorder, at which time the license becomes a marriage certificate.

Language in this section ("between a man and a woman") was held unconstitutional as a violation of the equal protection clause in the decision of In re Marriage Cases (2008) 76 Cal.Rptr.3d 683, 43 Cal.4th 757, 183 P.3d 384, rehearing denied, on subsequent appeal 2009 WL 2515727, unpublished.

CA FAM § 301 Adults; capability to consent to and consummate marriage

An unmarried male of the age of 18 years or older, and an unmarried female of the age of 18 years or older, and not otherwise disqualified, are capable of consenting to and consummating marriage.

PA FAM $\$ 308.5$ Between man and woman only

Only marriage between a man and a woman is valid or recognized in California.

This section was held unconstitutional as a violation of the equal protection clause in the decision of In re Marriage Cases (2008) 76 Cal.Rptr.3d 683, 43 Cal.4th 757, 183 P.3d 384, rehearing denied, on subsequent appeal 2009 WL 2515727, unpublished.

\section{Colorado}

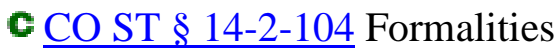

(1) Except as otherwise provided in subsection (3) of this section, a marriage is valid in this state if:

(a) It is licensed, solemnized, and registered as provided in this part 1; and

(b) It is only between one man and one woman.

(2) Notwithstanding the provisions of section 14-2-112, any marriage contracted within or outside this state that does not satisfy paragraph (b) of subsection (1) of this section shall not be recognized as valid in this state.

(3) Nothing in this section shall be deemed to repeal or render invalid any otherwise valid common law marriage between one man and one woman:

(a) Entered into prior to September 1, 2006; or 
(b) Entered into on or after September 1, 2006, that complies with section 14-2$\underline{109.5}$.

Connecticut - No DoMA

c CT ST \& 46b-20 Definitions

As used in this chapter:

(1) "Registrar" means the registrar of vital statistics;

(2) "Applicant" means applicant for a marriage license;

(3) "License" means marriage license; and

(4) "Marriage" means the legal union of two persons.

\section{Delaware}

c DE ST TI $13 \S 101$ Void and voidable marriages

(a) A marriage is prohibited and void between a person and his or her ancestor, descendant, brother, sister, half brother, half sister, uncle, aunt, niece, nephew, first cousin or between persons of the same gender.

(b) A marriage is prohibited, and is void from the time its nullity is declared by a court of competent jurisdiction at the instance of the innocent party, if either party thereto is:

(1) Repealed by 76 Laws 2007 , ch. $48, \S 1$, eff. June $21,2007$.

(2) Repealed by 76 Laws 2007 , ch. 48, § 1, eff. June 21, 2007.

(3) Repealed by 76 Laws 2007, ch. 48, § 1, eff. June 21, 2007.

(4) Repealed by 76 Laws 2007, ch. 48, § 1, eff. June 21, 2007.

(5) Repealed by 76 Laws 2007 , ch. 48, § 1, eff. June 21, 2007.

(6) Divorced, unless a certified copy of the divorce decree (last decree if such person has been divorced more than once) or a certificate of such divorce from the clerk of the court granting the divorce is inspected by the clerk of the peace to whom such person makes application for a marriage license, and unless such person may in other respects lawfully marry; and, if such decree or certificate cannot be obtained, the Resident Judge of the county where such license is desired or the person designated by the Resident Judge to grant such certificates as may be accepted under this paragraph may grant a certificate of the facts as stated by the applicant and the certificate may, for the purposes of this chapter, be accepted in lieu of a certified copy of a divorce decree;

(7) On probation or parole from any court or institution, unless such person first files with the clerk of the peace to whom such person makes application for a marriage license a written consent to such person's proposed marriage from the chief officer of such court or institution or from someone who is appointed by such officer to give such consent, and unless in other respects the applicant may lawfully marry.

(c) Repealed by 76 Laws 2007, ch. 48, § 1, eff. June 21, 2007.

(d) A marriage obtained or recognized outside the State between persons prohibited by subsection (a) of this section shall not constitute a legal or valid marriage within the State.

c DE ST TI $13 \S 104$ Entering into prohibited marriage outside the State; penalty 
If a marriage prohibited by this chapter is contracted or solemnized outside of the State, when the legal residence of either party to the marriage is in this State, and the parties thereto shall afterwards live and cohabit as spouses within the State, they shall be punished in the same manner as though the marriage had been contracted in this State.

\section{District of Columbia - No DoMA}

\section{Florida}

c FL ST $\$ 741.212$ Marriages between persons of the same sex

(1) Marriages between persons of the same sex entered into in any jurisdiction, whether within or outside the State of Florida, the United States, or any other jurisdiction, either domestic or foreign, or any other place or location, or relationships between persons of the same sex which are treated as marriages in any jurisdiction, whether within or outside the State of Florida, the United States, or any other jurisdiction, either domestic or foreign, or any other place or location, are not recognized for any purpose in this state.

(2) The state, its agencies, and its political subdivisions may not give effect to any public act, record, or judicial proceeding of any state, territory, possession, or tribe of the United States or of any other jurisdiction, either domestic or foreign, or any other place or location respecting either a marriage or relationship not recognized under subsection (1) or a claim arising from such a marriage or relationship.

(3) For purposes of interpreting any state statute or rule, the term "marriage" means only a legal union between one man and one woman as husband and wife, and the term "spouse" applies only to a member of such a union.

\section{Georgia}

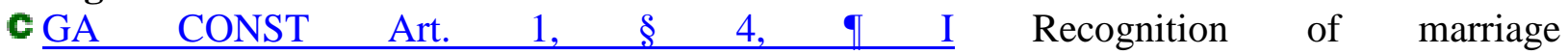

(a) This state shall recognize as marriage only the union of man and woman. Marriages between persons of the same sex are prohibited in this state.

(b) No union between persons of the same sex shall be recognized by this state as entitled to the benefits of marriage. This state shall not give effect to any public act, record, or judicial proceeding of any other state or jurisdiction respecting a relationship between persons of the same sex that is treated as a marriage under the laws of such other state or jurisdiction. The courts of this state shall have no jurisdiction to grant a divorce or separate maintenance with respect to any such relationship or otherwise to consider or rule on any of the parties' respective rights arising as a result of or in connection with such relationship.

\section{GA ST § 19-3-3.1 Same sex marriages prohibited}

(a) It is declared to be the public policy of this state to recognize the union only of man and woman. Marriages between persons of the same sex are prohibited in this state.

(b) No marriage between persons of the same sex shall be recognized as entitled to the benefits of marriage. Any marriage entered into by persons of the same sex pursuant to a 
marriage license issued by another state or foreign jurisdiction or otherwise shall be void in this state. Any contractual rights granted by virtue of such license shall be unenforceable in the courts of this state and the courts of this state shall have no jurisdiction whatsoever under any circumstances to grant a divorce or separate maintenance with respect to such marriage or otherwise to consider or rule on any of the parties' respective rights arising as a result of or in connection with such marriage.

\section{Hawaii}

\section{P $\underline{\text { HI CONST Art. } 1, \S 23}$ Marriage}

The legislature shall have the power to reserve marriage to opposite-sex couples.

\section{c $\underline{\text { HI ST } \$ 572-1}$ Requisites of valid marriage contract}

In order to make valid the marriage contract, which shall be only between a man and a woman, it shall be necessary that:

(1) The respective parties do not stand in relation to each other of ancestor and descendant of any degree whatsoever, brother and sister of the half as well as to the whole blood, uncle and niece, aunt and nephew, whether the relationship is the result of the issue of parents married or not married to each other;

(2) Each of the parties at the time of contracting the marriage is at least sixteen years of age; provided that with the written approval of the family court of the circuit within which the minor resides, it shall be lawful for a person under the age of sixteen years, but in no event under the age of fifteen years, to marry, subject to section $572-2$;

(3) The man does not at the time have any lawful wife living and that the woman does not at the time have any lawful husband living;

(4) Consent of neither party to the marriage has been obtained by force, duress, or fraud;

(5) Neither of the parties is a person afflicted with any loathsome disease concealed from, and unknown to, the other party;

(6) The man and woman to be married in the State shall have duly obtained a license for that purpose from the agent appointed to grant marriage licenses; and

(7) The marriage ceremony be performed in the State by a person or society with a valid license to solemnize marriages and the man and the woman to be married and the person performing the marriage ceremony be all physically present at the same place and time for the marriage ceremony.

\section{P $\underline{\text { HI ST } ~ § ~ 572-1.5 ~ D e f i n i t i o n ~ o f ~ m a r r i a g e ~}$}

Whenever used in the statutes or other laws of Hawaii, "marriage" means the union licensed under section 572-1.

P $\underline{\text { HI ST } \S 572-3}$ Contracted without the State 
Marriages between a man and a woman legal in the country where contracted shall be held legal in the courts of this State.

\section{Idaho}

c ID CONST Art. III, $§ 28$ Marriage

A marriage between a man and a woman is the only domestic legal union that shall be valid or recognized in this state.

c ID ST § 32-201 What constitutes marriage--No common-law marriage after January 1, 1996

(1) Marriage is a personal relation arising out of a civil contract between a man and a woman, to which the consent of parties capable of making it is necessary. Consent alone will not constitute marriage; it must be followed by the issuance of a license and a solemnization as authorized and provided by law. Marriage created by a mutual assumption of marital rights, duties or obligations shall not be recognized as a lawful marriage.

(2) The provisions of subsection (1) of this section requiring the issuance of a license and a solemnization shall not invalidate any marriage contract in effect prior to January 1, 1996, created by consenting parties through a mutual assumption of marital rights, duties or obligations.

c ID ST § 32-209 Recognition of foreign or out-of-state marriages

All marriages contracted without this state, which would be valid by the laws of the state or country in which the same were contracted, are valid in this state, unless they violate the public policy of this state. Marriages that violate the public policy of this state include, but are not limited to, same-sex marriages, and marriages entered into under the laws of another state or country with the intent to evade the prohibitions of the marriage laws of this state.

\section{Illinois}

PIL ST CH $750 \S 5 / 201$ Formalities

A marriage between a man and a woman licensed, solemnized and registered as provided in this Act is valid in this State.

\section{P $\underline{\text { IL ST CH } 750 \S 5 / 212}$ Prohibited Marriages}

(a) The following marriages are prohibited:

(1) a marriage entered into prior to the dissolution of an earlier marriage of one of the parties;

(2) a marriage between an ancestor and a descendant or between a brother and a sister, whether the relationship is by the half or the whole blood or by adoption; 
(3) a marriage between an uncle and a niece or between an aunt and a nephew, whether the relationship is by the half or the whole blood;

(4) a marriage between cousins of the first degree; however, a marriage between first cousins is not prohibited if:

(i) both parties are 50 years of age or older; or

(ii) either party, at the time of application for a marriage license, presents for filing with the county clerk of the county in which the marriage is to be solemnized, a certificate signed by a licensed physician stating that the party to the proposed marriage is permanently and irreversibly sterile;

(5) a marriage between 2 individuals of the same sex.

(b) Parties to a marriage prohibited under subsection (a) of this Section who cohabit after removal of the impediment are lawfully married as of the date of the removal of the impediment.

(c) Children born or adopted of a prohibited or common law marriage are the lawful children of the parties.

\section{C $\underline{\text { IL ST CH } 750 \S 5 / 213}$ Validity}

All marriages contracted within this State, prior to the effective date of this Act, or outside this State, that were valid at the time of the contract or subsequently validated by the laws of the place in which they were contracted or by the domicile of the parties, are valid in this State, except where contrary to the public policy of this State.

P $\underline{\text { IL ST CH } 750 § 5 / 213.1 ~ S a m e-s e x ~ m a r r i a g e s ; ~ p u b l i c ~ p o l i c y ~}$

A marriage between 2 individuals of the same sex is contrary to the public policy of this State.

c $\underline{\text { IL ST CH } 750 \S 5 / 216}$ Prohibited marriages void if contracted in another state

That if any person residing and intending to continue to reside in this state and who is disabled or prohibited from contracting marriage under the laws of this state, shall go into another state or country and there contract a marriage prohibited and declared void by the laws of this state, such marriage shall be null and void for all purposes in this state with the same effect as though such prohibited marriage had been entered into in this state.

\section{Indiana}

c IN ST 31-11-1-1 Same sex marriages prohibited

(a) Only a female may marry a male. Only a male may marry a female.

(b) A marriage between persons of the same gender is void in Indiana even if the marriage is lawful in the place where it is solemnized.

\section{Iowa}


PIA ST \& 595.2 Gender-age

1. Only a marriage between a male and a female is valid.

Held unconstitutional (Varnum v. Brien, 2009)

c $\underline{\text { IA ST } § 595.3}$ License

C IA ST § 595.20 Foreign marriages--validity

$\begin{array}{llllll}\text { Kansas } & \text { 23-2501 } & \text { Nature } & \text { of marriage relation }\end{array}$

The marriage contract is to be considered in law as a civil contract between two parties who are of opposite sex. All other marriages are declared to be contrary to the public policy of this state and are void. The consent of the parties is essential. The marriage ceremony may be regarded either as a civil ceremony or as a religious sacrament, but the marriage relation shall only be entered into, maintained or abrogated as provided by law.

c KS ST 23-115 Validity of marriages contracted without state

All marriages contracted without this state, which would be valid by the laws of the country in which the same were contracted, shall be valid in all courts and places in this state. It is the strong public policy of this state only to recognize as valid marriages from other states that are between a man and a woman.

\section{Kentucky}

c $\underline{\text { KY Const } \S 233 \mathrm{~A}}$ Valid or recognized marriage; status of unmarried individuals

Only a marriage between one man and one woman shall be valid or recognized as a marriage in Kentucky. A legal status identical or substantially similar to that of marriage for unmarried individuals shall not be valid or recognized.

c KY ST $\S 402.005$ Definition of marriage

As used and recognized in the law of the Commonwealth, "marriage" refers only to the civil status, condition, or relation of one (1) man and one (1) woman united in law for life, for the discharge to each other and the community of the duties legally incumbent upon those whose association is founded on the distinction of sex.

C $\underline{\text { KY ST } \$ 402.020}$ Other prohibited marriages

(1) Marriage is prohibited and void: 
(a) With a person who has been adjudged mentally disabled by a court of competent jurisdiction;

(b) Where there is a husband or wife living, from whom the person marrying has not been divorced;

(c) When not solemnized or contracted in the presence of an authorized person or society;

(d) Between members of the same sex;

(e) Between more than two (2) persons.

C $\underline{\text { KY ST } \S 402.030}$ Courts may declare certain marriages void

c KY ST $\$ 402.040$ Marriage in another state

(1) If any resident of this state marries in another state, the marriage shall be valid here if valid in the state where solemnized, unless the marriage is against Kentucky public policy.

(2) A marriage between members of the same sex is against Kentucky public policy and shall be subject to the prohibitions established in KRS 402.045.

C $\underline{\text { KY ST } \S 402.045}$ Same-sex marriage in another jurisdiction void and unenforceable

(1) A marriage between members of the same sex which occurs in another jurisdiction shall be void in Kentucky.

(2) Any rights granted by virtue of the marriage, or its termination, shall be unenforceable in Kentucky courts.

\section{Louisiana}

c LA CONST Art. 12, $§ 15$ Defense of Marriage

Marriage in the state of Louisiana shall consist only of the union of one man and one woman. No official or court of the state of Louisiana shall construe this constitution or any state law to require that marriage or the legal incidents thereof be conferred upon any member of a union other than the union of one man and one woman. A legal status identical or substantially similar to that of marriage for unmarried individuals shall not be valid or recognized. No official or court of the state of Louisiana shall recognize any marriage contracted in any other jurisdiction which is not the union of one man and one woman.

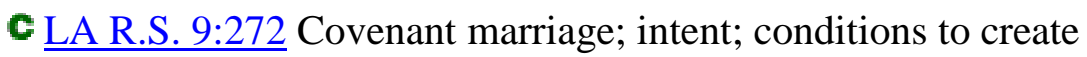

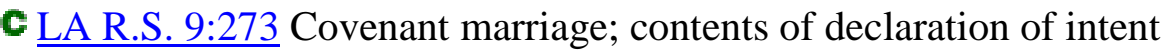

c $\underline{\text { LA C.C. Art. } 89}$ Impediment of same sex 
Persons of the same sex may not contract marriage with each other. A purported marriage between persons of the same sex contracted in another state shall be governed by the provisions of Title II of Book IV of the Civil Code.

c LA C.C. Art. 3520 Marriage

A. A marriage that is valid in the state where contracted, or in the state where the parties were first domiciled as husband and wife, shall be treated as a valid marriage unless to do so would violate a strong public policy of the state whose law is applicable to the particular issue under Article 3519.

B. A purported marriage between persons of the same sex violates a strong public policy of the state of Louisiana and such a marriage contracted in another state shall not be recognized in this state for any purpose, including the assertion of any right or claim as a result of the purported marriage.

c LSA-C.C. Art. 3522 Effects and incidents of marriage and of divorce

Unless otherwise provided by the law of this state, the effects and incidents of marriage and of divorce with regard to an issue are governed by the law applicable to that issue under Article 3519.

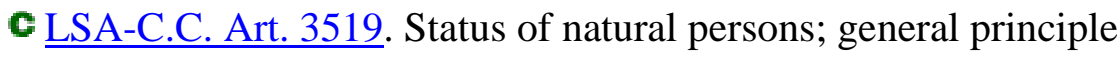

The status of a natural person and the incidents and effects of that status are governed by the law of the state whose policies would be most seriously impaired if its law were not applied to the particular issue.

That state is determined by evaluating the strength and pertinence of the relevant policies of the involved states in the light of: (1) the relationship of each state, at any pertinent time, to the dispute, the parties, and the person whose status is at issue; (2) the policies referred to in Article 3515; and (3) the policies of sustaining the validity of obligations voluntarily undertaken, of protecting children, minors, and others in need of protection, and of preserving family values and stability.

\section{c LSA-C.C. Art. 3515. Determination of the applicable law; general and residual rule}

Except as otherwise provided in this Book, an issue in a case having contacts with other states is governed by the law of the state whose policies would be most seriously impaired if its law were not applied to that issue.

That state is determined by evaluating the strength and pertinence of the relevant policies of all involved states in the light of: (1) the relationship of each state to the parties and the dispute; and (2) the policies and needs of the interstate and international systems, 
including the policies of upholding the justified expectations of parties and of minimizing the adverse consequences that might follow from subjecting a party to the law of more than one state.

\section{Maine}

c ME ST T. 19-A $\S 650$ Findings and purposes

All municipal clerks and courts of this State shall have a duty and shall be legally required to construe the provisions of Maine's marriage laws in accordance with the following findings and purposes:

1. Findings. The people of the State of Maine find that:

A. The union of one man and one woman joined in traditional monogamous marriage is of inestimable value to society; the State has a compelling interest to nurture and promote the unique institution of traditional monogamous marriage in the support of harmonious families and the physical and mental health of children; and that the State has the compelling interest in promoting the moral values inherent in traditional monogamous marriage.

2. Purposes. The purposes of this chapter are:

A. To encourage the traditional monogamous family unit as the basic building block of our society, the foundation of harmonious and enriching family life;

B. To nurture, sustain and protect the traditional monogamous family unit in Maine society, its moral imperatives, its economic function and its unique contribution to the rearing of healthy children; and

C. To support and strengthen traditional monogamous Maine families against improper interference from out-of-state influences or edicts.

ME ST T. 19-A § 701 Prohibited marriages; exceptions

1-A. Certain marriages performed in another state not recognized in this State. Any marriage performed in another state that would violate any provisions of subsections 2 to 5 if performed in this State is not recognized in this State and is considered void if the parties take up residence in this State.

5. Same sex marriage prohibited. Persons of the same sex may not contract marriage.

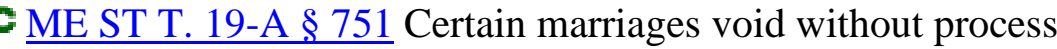

The following marriages are void and dissolved without legal process:

1. Solemnized in State. A marriage prohibited in section 701, if solemnized in this State.

\section{Maryland}

P MD FAMILY $\$ 2-201$ Marriages which are valid

Only a marriage between a man and a woman is valid in this State.

\section{Massachusetts - No DoMA}




\section{Michigan}

c MI CONST Art. 1, §25 Union of one man and one woman as only agreement recognized as marriage or similar union

To secure and preserve the benefits of marriage for our society and for future generations of children, the union of one man and one woman in marriage shall be the only agreement recognized as a marriage or similar union for any purpose.

c MI ST 551.1 Marriage between same sex, invalidity

Marriage is inherently a unique relationship between a man and a woman. As a matter of public policy, this state has a special interest in encouraging, supporting, and protecting that unique relationship in order to promote, among other goals, the stability and welfare of society and its children. A marriage contracted between individuals of the same sex is invalid in this state.

P MI ST 551.2 Marriage as civil contract; consent; license; solemnization

$P$ MI ST 551.3 Incapacity; persons man prohibited from marrying

A man shall not marry his mother, sister, grandmother, daughter, granddaughter, stepmother, grandfather's wife, son's wife, grandson's wife, wife's mother, wife's grandmother, wife's daughter, wife's granddaughter, brother's daughter, sister's daughter, father's sister, mother's sister, or cousin of the first degree, or another man.

c MI ST 551.4 Incapacity; persons woman prohibited from marrying

A woman shall not marry her father, brother, grandfather, son, grandson, stepfather, grandmother's husband, daughter's husband, granddaughter's husband, husband's father, husband's grandfather, husband's son, husband's grandson, brother's son, sister's son, father's brother, mother's brother, or cousin of the first degree, or another woman.

MI ST 551.271 Marriages solemnized in another state validated

MI ST 551.272 Recognition of nature of marriage relationship; marriage not between man and woman invalidated

Sec. 1. (1) Except as otherwise provided in this act, a marriage contracted between a man and a woman who are residents of this state and who were, at the time of the marriage, legally competent to contract marriage according to the laws of this state, which marriage is solemnized in another state within the United States by a clergyman, magistrate, or other person legally authorized to solemnize marriages within that state, is a valid and binding marriage under the laws of this state to the same effect and extent as if solemnized within this state and according to its laws . 
(2) This section does not apply to a marriage contracted between individuals of the same sex, which marriage is invalid in this state under section 1 of chapter 83 of the revised statutes of 1846, being section 551.1 of the Michigan Compiled Laws.

\section{Minnesota}

C $\underline{\text { MN ST } \$ 517.01}$ Marriage a civil contract

Marriage, so far as its validity in law is concerned, is a civil contract between a man and a woman, to which the consent of the parties, capable in law of contracting, is essential. Lawful marriage may be contracted only between persons of the opposite sex and only when a license has been obtained as provided by law and when the marriage is contracted in the presence of two witnesses and solemnized by one authorized, or whom one or both of the parties in good faith believe to be authorized, so to do. Marriages subsequent to April 26, 1941, not so contracted shall be null and void.

\section{c MN ST § 517.03 Prohibited marriages}

(a) The following marriages are prohibited:

(4) a marriage between persons of the same sex.

(b) A marriage entered into by persons of the same sex, either under common law or statute, that is recognized by another state or foreign jurisdiction is void in this state and contractual rights granted by virtue of the marriage or its termination are unenforceable in this state.

\section{Mississippi \\ c MS CONST Art. 14, § 263A Marriage}

Marriage may take place and may be valid under the laws of this state only between a man and a woman. A marriage in another state or foreign jurisdiction between persons of the same gender, regardless of when the marriage took place, may not be recognized in this state and is void and unenforceable under the laws of this state.

\section{MS ST § 93-1-1 Incestuous marriages void}

(2) Any marriage between persons of the same gender is prohibited and null and void from the beginning. Any marriage between persons of the same gender that is valid in another jurisdiction does not constitute a legal or valid marriage in Mississippi.

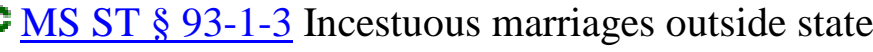

Any attempt to evade section 93-1-1 by marrying out of this state and returning to it shall be within the prohibitions of said section.

\section{Missouri}

c MO CONST Art. $1, \S 33$ Only marriage between a man and a woman recognized as valid 
That to be valid and recognized in this state, a marriage shall exist only between a man and a woman.

c MO ST 451.022 Marriage, public policy, validity--marriage licenses, issued, when

1. It is the public policy of this state to recognize marriage only between a man and a woman.

2. Any purported marriage not between a man and a woman is invalid.

3. No recorder shall issue a marriage license, except to a man and a woman.

4. A marriage between persons of the same sex will not be recognized for any purpose in this state even when valid where contracted.

\section{Montana}

c MT CONST Art. 13, $\$ 7$ Marriage

Only a marriage between one man and one woman shall be valid or recognized as a marriage in this state.

\section{c MT ST 40-1-103 Formalities}

Marriage is a personal relationship between a man and a woman arising out of a civil contract to which the consent of the parties is essential. A marriage licensed, solemnized, and registered as provided in this chapter is valid in this state. A marriage may be contracted, maintained, invalidated, or dissolved only as provided by the law of this state.

c MT ST 40-1-401 Prohibited marriages -- contracts

(1) The following marriages are prohibited:

(d) a marriage between persons of the same sex.

(4) A contractual relationship entered into for the purpose of achieving a civil relationship that is prohibited under subsection (1) is void as against public policy.

\section{Nebraska}

P NE CONST Art. I, § 29 Marriage; same-sex relationships not valid or recognized

Only marriage between a man and a woman shall be valid or recognized in Nebraska. The uniting of two persons of the same sex in a civil union, domestic partnership, or other similar same-sex relationship shall not be valid or recognized in Nebraska.

Declared unconstitutional by Citizens for Equal Protection, Inc. v. Bruning, 368 F.Supp.2d 980 (2005). That decision was then reversed by Citizens for Equal Protection, Inc. v. Bruning, 455 F.3d 859 (2006).

C NE ST § 42-117 Marriage contracted out of state; when valid 
All marriages contracted without this state, which would be valid by the laws of the country in which the same were contracted, shall be valid in all courts and places in this state.

\section{Nevada}

c NV CONST Art. $1, \S 21$ Limitation on recognition of marriage

Only a marriage between a male and female person shall be recognized and given effect in this state.

c NV ST 122.020 Persons capable of marriage; consent of parent or guardian

1. Except as otherwise provided in this section, a male and a female person, at least 18 years of age, not nearer of kin than second cousins or cousins of the half blood, and not having a husband or wife living, may be joined in marriage.

2. A male and a female person who are the husband and wife of each other may be rejoined in marriage if the record of their marriage has been lost or destroyed or is otherwise unobtainable.

\section{New Hampshire - No DoMA}

$P$ NH ST $\S 457: 1$ Purpose and Intent

The purpose of this chapter is to affirm the right of 2 individuals desiring to marry and who otherwise meet the eligibility requirements of this chapter to have their marriage solemnized in a religious or civil ceremony in accordance with the provisions of this chapter.

NH ST § 457:1-a Equal Access to Marriage

Marriage is the legally recognized union of 2 people. Any person who otherwise meets the eligibility requirements of this chapter may marry any other eligible person regardless of gender. Each party to a marriage shall be designated "bride," "groom," or "spouse."

c NH ST § 457:2 Marriages Prohibited

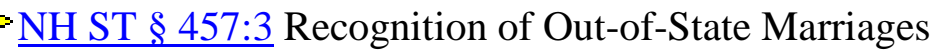

P NH ST § 457:43 Residents

\section{New Jersey - No DoMA}

c NJ ST 37:1-1 Certain marriages or civil unions prohibited

Atty.Gen. F.O.2007, No. 3. [Not part of statute] New Jersey will recognize as valid, same-sex relationships formed under the laws of other States and foreign nations that most closely approximate those of New Jersey civil unions or comparable relationships; and, couples in these relationships need not secure a New Jersey Civil union license or 
solemnize their relationships in the State to enjoy all of the rights and obligations under State law.

\section{c NJ ST 37:1-28 Legislative findings and declarations}

The bill provides that parties to a civil union would have all the same benefits, protections and responsibilities under law, whether they derive from statute, administrative or court rule, public policy, common law or any other source of civil law, as are granted to spouses in a marriage. They may modify the terms, conditions or effects of their civil union in the same manner and to the same extent as married persons who execute an antenuptial agreement or other agreement recognized and enforceable under the law, setting forth particular understandings with respect to their union. They would be responsible for the support of one another to the same degree and in the same manner as prescribed under law for married persons. The dissolution of civil unions would also follow the same procedures and be subject to the same substantive rights and obligations that are involved in the dissolution of a marriage.

The laws of domestic relations, including annulment, premarital agreements, separation, divorce, child custody and support, property division and maintenance, and post relationship spousal support, would apply to civil union couples. Also, the rights of the couples, with respect to a child of whom either becomes the natural parent during the term of the civil union, would be the same as those of a married couple, with respect to a child of whom either spouse becomes the natural parent during the marriage.

The bill enumerates some legal benefits, protections and responsibilities of spouses which would apply in like manner to civil union couples, however, this list should not be construed to be an exclusive list of such benefits, protections and responsibilities: (1) laws relating to title, tenure, descent and distribution, intestate succession, survivorship, or other incidents of the acquisition, ownership or transfer, inter vivos or at death, of real or personal property, including eligibility to hold real and personal property as tenants by the entirety; (2) causes of action related to or dependent upon spousal status, including an action for wrongful death, emotional distress, loss of consortium, or other torts or actions under contracts reciting, related to, or dependent upon spousal status; (3) probate law and procedure, including nonprobate transfer; (4) adoption law and procedures; (5) laws relating to insurance, health and pension benefits; (6) domestic violence protections and domestic violence programs; (7) prohibitions against discrimination based upon marital status; (8) victim's compensation benefits, including compensation to spouse, children and relatives of homicide victims; (9) workers' compensation benefits pursuant to chapter 15 of Title 34 of the Revised Statutes, including survivors benefits and payment of back wages; (10) laws relating to emergency and nonemergency medical care and treatment, hospital visitation and notification, and any rights guaranteed to a hospital patient or a nursing home resident; (11) advance directives for health care and designation as a health care representative; (12) family leave benefits; (13) public assistance benefits, medical assistance, Supplemental Security Income, pharmaceutical assistance, hearing aid assistance, and utility benefits; (14) laws relating to taxes imposed by the State or a municipality, including tax deduction based on marital status or exemptions from realty 
transfer tax based on marital status; (15) laws relating to immunity from compelled testimony and the marital communication privilege; (16) the home ownership rights of a surviving spouse; (17) the right of a spouse to a surname change without petitioning the court; (18) laws relating to the making of, revoking and objecting to anatomical gifts; (19) State pay for military service; (20) application for absentee ballots; (21) legal requirements for assignment of wages; and (22) laws related to tuition assistance for higher education for surviving spouses or children.

\section{Dissolution of civil unions, equitable distribution and legal separation of civil union} partners. The dissolution of a civil union would follow the same procedures and be subject to the same substantive rights and obligations as are involved in the dissolution of marriage, including any residency requirements. The bill provides for the following ground for the dissolution of civil unions: voluntary sexual intercourse between a person who is in a civil union and an individual other than the person's partner; willful and continued desertion for a period of 12 or more consecutive months, which may be established by satisfactory proof that the partners have ceased to cohabit as a couple; extreme cruelty; separation for a period of at least 18 or more consecutive months; voluntarily induced addiction or habituation or habitual drunkenness for a period of 12 or more consecutive months; institutionalization for mental illness for a period of 24; or imprisonment of the defendant for 18 or more consecutive months.

The bill would also provide for legal separation for a civil union couple. The current equitable distribution statute would be amended to provide for distribution of the property which was legally and beneficially acquired by the civil union couple or either of them during the civil union. In addition, the bill provides for alimony and maintenance upon dissolution of a civil union. The court, upon or after granting a dissolution of the civil union to either person, may allow either person to resume any name used by the partner before the civil union, or to assume any surname.

The Superior Court would have jurisdiction over dissolution of a civil unions and legal separations from a civil union partner. The filings fees for an action or proceeding for the dissolution of a civil union would be the same as those for filing divorce proceedings or actions

\section{NJ ST 37:1-29 Definitions}

\section{NJ ST 37:1-30 Criteria to establish civil union}

\section{NJ ST 37:1-31 Rights and responsibilities of civil union couples}

a. Civil union couples shall have all of the same benefits, protections and responsibilities under law, whether they derive from statute, administrative or court rule, public policy, common law or any other source of civil law, as are granted to spouses in a marriage. 
b. The dissolution of civil unions shall follow the same procedures and be subject to the same substantive rights and obligations that are involved in the dissolution of marriage.

c. The laws of domestic relations, including annulment, premarital agreements, separation, divorce, child custody and support, property division and maintenance, and post-relationship spousal support, shall apply to civil union couples.

d. Civil union couples may modify the terms, conditions or effects of their civil union in the same manner and to the same extent as married persons who execute an antenuptial agreement or other agreement recognized and enforceable under the law, setting forth particular understandings with respect to their union.

e. The rights of civil union couples with respect to a child of whom either becomes the parent during the term of the civil union, shall be the same as those of a married couple with respect to a child of whom either spouse or partner in a civil union couple becomes the parent during the marriage.

f. All contracts made between persons in contemplation of a civil union shall remain in full force after such civil union takes place.

g. A copy of the record of the civil union received from the local or State registrar shall be presumptive evidence of the civil union in all courts.

PNJ ST 37:1-32 Applicable legal benefits, protections and responsibilities

NJ ST 37:1-33 References to marital or spousal relationships include civil union relationships

c NJ ST 37:1-34 Validity of foreign civil unions

A civil union relationship entered into outside of this State, which is valid under the laws of the jurisdiction under which the civil union relationship was created, shall be valid in this State.

NJ ST 37:1-35 Rules and regulations governing civil unions

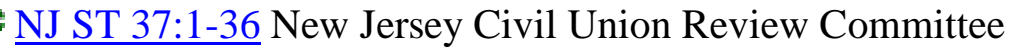

New Mexico - No DoMA

PNM ST § 40-1-4 Lawful marriages without the state recognized

All marriages celebrated beyond the limits of this state, which are valid according to the laws of the country wherein they were celebrated or contracted, shall be likewise valid in this state, and shall have the same force as if they had been celebrated in accordance with the laws in force in this state.

New York - No DoMA 


\section{North Carolina}

PNC ST \& 51-1 Requisites of marriage; solemnization

A valid and sufficient marriage is created by the consent of a male and female person who may lawfully marry, presently to take each other as husband and wife, freely, seriously and plainly expressed by each in the presence of the other, either:

(1) a. In the presence of an ordained minister of any religious denomination, a minister authorized by a church, or a magistrate; and

b. With the consequent declaration by the minister or magistrate that the persons are husband and wife; or

(2) In accordance with any mode of solemnization recognized by any religious denomination, or federally or State recognized Indian Nation or Tribe.

Marriages solemnized before March 9, 1909, by ministers of the gospel licensed, but not ordained, are validated from their consummation.

C NC ST § 51-1.2 Marriages between persons of the same gender not valid

Marriages, whether created by common law, contracted, or performed outside of North Carolina, between individuals of the same gender are not valid in North Carolina.

\section{North Dakota}

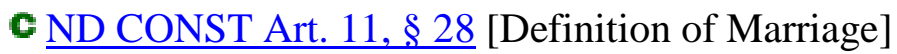

Marriage consists only of the legal union between a man and a woman. No other domestic union, however denominated, may be recognized as a marriage or given the same or substantially equivalent legal effect.

c ND ST 14-03-01 What constitutes marriage - Spouse defined

Marriage is a personal relation arising out of a civil contract between one man and one woman to which the consent of the parties is essential. The marriage relation may be entered into, maintained, annulled, or dissolved only as provided by law. A spouse refers only to a person of the opposite sex who is a husband or a wife.

\section{c ND ST 14-03-08 Foreign marriages recognized - Exception}

Except when residents of this state contract a marriage in another state which is prohibited under the laws of this state, all marriages contracted outside this state, which are valid according to the laws of the state or country where contracted, are valid in this state. This section applies only to a marriage contracted in another state or country which is between one man and one woman as husband and wife.

\section{Ohio}

P OH CONST Art. XV, $\S 11$ Defense of marriage 
Only a union between one man and one woman may be a marriage valid in or recognized by this state and its political subdivisions. This state and its political subdivisions shall not create or recognize a legal status for relationships of unmarried individuals that intends to approximate the design, qualities, significance or effect of marriage.

Held unconstitutional for denying non-married domestic abuse victims access to Domestic Violence act. Still constitutional regarding same sex marriage. Phelps $v$. Johnson, NO. DV05 30564, 2005 WL 4651081 (Ohio Com.Pl. Nov 28, 2005)

POH ST \& 3101.01 Persons who may marry; same sex marriages against public policy; recognition or extension by state of specific statutory benefits of legal marriage to nonmarital relationships against public policy

(C)(1) Any marriage between persons of the same sex is against the strong public policy of this state. Any marriage between persons of the same sex shall have no legal force or effect in this state and, if attempted to be entered into in this state, is void ab initio and shall not be recognized by this state.

(2) Any marriage entered into by persons of the same sex in any other jurisdiction shall be considered and treated in all respects as having no legal force or effect in this state and shall not be recognized by this state.

(3) The recognition or extension by the state of the specific statutory benefits of a legal marriage to nonmarital relationships between persons of the same sex or different sexes is against the strong public policy of this state. Any public act, record, or judicial proceeding of this state, as defined in section 9.82 of the Revised Code, that extends the specific statutory benefits of legal marriage to nonmarital relationships between persons of the same sex or different sexes is void ab initio. Nothing in division (C)(3) of this section shall be construed to do either of the following:

(a) Prohibit the extension of specific benefits otherwise enjoyed by all persons, married or unmarried, to nonmarital relationships between persons of the same sex or different sexes, including the extension of benefits conferred by any statute that is not expressly limited to married persons, which includes but is not limited to benefits available under Chapter 4117. of the Revised Code;

(b) Affect the validity of private agreements that are otherwise valid under the laws of this state.

(4) Any public act, record, or judicial proceeding of any other state, country, or other jurisdiction outside this state that extends the specific benefits of legal marriage to nonmarital relationships between persons of the same sex or different sexes shall be considered and treated in all respects as having no legal force or effect in this state and shall not be recognized by this state.

\section{Oklahoma}

c OK CONST Art. 2, $\$ 35$ Marriage defined--Construction of law and Constitution-Recognition of out-of-state marriages--Penalty 
A. Marriage in this state shall consist only of the union of one man and one woman. Neither this Constitution nor any other provision of law shall be construed to require that marital status or the legal incidents thereof be conferred upon unmarried couples or groups.

B. A marriage between persons of the same gender performed in another state shall not be recognized as valid and binding in this state as of the date of the marriage.

C. Any person knowingly issuing a marriage license in violation of this section shall be guilty of a misdemeanor.

c OK ST T. $43 \S 3$ Who may marry

c OK ST T. $43 \S 3.1$ Recognition of marriage between persons of same gender prohibited

A marriage between persons of the same gender performed in another state shall not be recognized as valid and binding in this state as of the date of the marriage.

\section{Oregon}

c OR CONST Art. XV, $\S 5$ a Marriage policy

It is the policy of Oregon, and its political subdivisions, that only a marriage between one man and one woman shall be valid or legally recognized as a marriage.

$\underline{\text { OR ST } \S 106.010}$ Marriage contract; age of parties

\section{Pennsylvania}

P23 Pa.C.S.A. $§ 1102$ Definitions

The following words and phrases when used in this part shall have the meanings given to them in this section unless the context clearly indicates otherwise:

"Marriage." A civil contract by which one man and one woman take each other for husband and wife.

c 23 Pa.C.S.A. $\S 1704$ Marriage between persons of the same sex

It is hereby declared to be the strong and longstanding public policy of this Commonwealth that marriage shall be between one man and one woman. A marriage between persons of the same sex which was entered into in another state or foreign jurisdiction, even if valid where entered into, shall be void in this Commonwealth.

\section{Rhode Island - No DoMA}

\section{South Carolina}

c $\underline{\text { SC ST } \$ 20-1-10}$ Persons who may contract matrimony 
(A) All persons, except mentally incompetent persons and persons whose marriage is prohibited by this section, may lawfully contract matrimony.

(B) No man shall marry his mother, grandmother, daughter, granddaughter, stepmother, sister, grandfather's wife, son's wife, grandson's wife, wife's mother, wife's grandmother, wife's daughter, wife's granddaughter, brother's daughter, sister's daughter, father's sister, mother's sister, or another man.

(C) No woman shall marry her father, grandfather, son, grandson, stepfather, brother, grandmother's husband, daughter's husband, granddaughter's husband, husband's father, husband's grandfather, husband's son, husband's grandson, brother's son, sister's son, father's brother, mother's brother, or another woman.

c SC ST $\S 20-1-15$ Prohibition of same sex marriage

A marriage between persons of the same sex is void ab initio and against the public policy of this State.

\section{South Dakota}

c SD CONST Art. 21, $\$ 9$ Marriage

Only marriage between a man and a woman shall be valid or recognized in South Dakota. The uniting of two or more persons in a civil union, domestic partnership, or other quasimarital relationship shall not be valid or recognized in South Dakota.

c $\underline{\text { SD ST } § 25-1-1}$ Marriage defined--Consent and solemnization required

Marriage is a personal relation, between a man and a woman, arising out of a civil contract to which the consent of parties capable of making it is necessary. Consent alone does not constitute a marriage; it must be followed by a solemnization.

c SD ST $\S 25-1-38$ Validity of marriages contracted outside state--Same-sex marriages excluded

Any marriage contracted outside the jurisdiction of this state, except a marriage contracted between two persons of the same gender, which is valid by the laws of the jurisdiction in which such marriage was contracted, is valid in this state.

\section{Tennessee}

c TN ST $\S 36-3-113$ Enforceability of same sex marriages

(a) Tennessee's marriage licensing laws reinforce, carry forward, and make explicit the long-standing public policy of this state to recognize the family as essential to social and economic order and the common good and as the fundamental building block of our society. To that end, it is further the public policy of this state that the historical institution and legal contract solemnizing the relationship of one (1) man and one (1) 
woman shall be the only legally recognized marital contract in this state in order to provide the unique and exclusive rights and privileges to marriage.

(b) The legal union in matrimony of only one (1) man and one (1) woman shall be the only recognized marriage in this state.

(c) Any policy, law or judicial interpretation that purports to define marriage as anything other than the historical institution and legal contract between one (1) man and one (1) woman is contrary to the public policy of Tennessee.

(d) If another state or foreign jurisdiction issues a license for persons to marry, which marriages are prohibited in this state, any such marriage shall be void and unenforceable in this state.

\section{Texas}

c TX CONST Art. $1, \S 32$ Marriage; union of one man and one woman

(a) Marriage in this state shall consist only of the union of one man and one woman.

(b) This state or a political subdivision of this state may not create or recognize any legal status identical or similar to marriage.

c TX FAMILY § 1.103 Persons Married Elsewhere

The law of this state applies to persons married elsewhere who are domiciled in this state.

c TX FAMILY § 2.001 Marriage License

(a) A man and a woman desiring to enter into a ceremonial marriage must obtain a marriage license from the county clerk of any county of this state.

(b) A license may not be issued for the marriage of persons of the same sex.

\section{c TX FAMILY $\S 6.204$ Recognition of Same-Sex Marriage or Civil Union}

(a) In this section, "civil union" means any relationship status other than marriage that:

(1) is intended as an alternative to marriage or applies primarily to cohabitating persons; and

(2) grants to the parties of the relationship legal protections, benefits, or responsibilities granted to the spouses of a marriage.

(b) A marriage between persons of the same sex or a civil union is contrary to the public policy of this state and is void in this state.

(c) The state or an agency or political subdivision of the state may not give effect to a:

(1) public act, record, or judicial proceeding that creates, recognizes, or validates a marriage between persons of the same sex or a civil union in this state or in any other jurisdiction; or 
(2) right or claim to any legal protection, benefit, or responsibility asserted as a result of a marriage between persons of the same sex or a civil union in this state or in any other jurisdiction.

\section{Utah}

c UT CONST Art. 1, § 29 [Marriage]

(1) Marriage consists only of the legal union between a man and a woman.

(2) No other domestic union, however denominated, may be recognized as a marriage or given the same or substantially equivalent legal effect.

c UT ST $\$ 30-1-2$ Marriages prohibited and void

The following marriages are prohibited and declared void:

(5) between persons of the same sex.

c UT ST § 30-1-4 Validity of foreign marriages-Exceptions

A marriage solemnized in any other country, state, or territory, if valid where solemnized, is valid here, unless it is a marriage:

(1) that would be prohibited and declared void in this state, under Subsection 301-2(1), (3), or (5); or

(2) between parties who are related to each other within and including three degrees of consanguinity, except as provided in Subsection 30-1-1(2).

c UT ST \& 30-1-4.1 Marriage recognition policy

(1)(a) It is the policy of this state to recognize as marriage only the legal union of a man and a woman as provided in this chapter.

(b) Except for the relationship of marriage between a man and a woman recognized pursuant to this chapter, this state will not recognize, enforce, or give legal effect to any law creating any legal status, rights, benefits, or duties that are substantially equivalent to those provided under Utah law to a man and a woman because they are married.

(2) Nothing in Subsection (1) impairs any contract or other rights, benefits, or duties that are enforceable independently of this section.

\section{Vermont - No DoMA}

P VT ST T. $15 \S 8$ Marriage definition

Marriage is the legally recognized union of two people. When used in this chapter or in any other statute, the word "marriage" shall mean a civil marriage. Terms relating to the marital relationship or familial relationships shall be construed consistently with this section for all purposes throughout the law, whether in the context of statute, administrative or court rule, policy, common law, or any other source of civil law. 


\section{PVT ST T. $15 \S 1201$ Definitions}

Parties to a civil union shall have all of the same benefits, protections and responsibilities under state law, whether derived from statute, administrative or court rule, policy, common law or any other source of civil law, as are granted to spouses in a marriage.

PVT ST T. $15 \S 1202$ Requisites of a valid civil union

VT ST T. $15 \$ 1203$ Person shall not enter a civil union with a relative

c VT ST T. $15 \S 1204$ Benefits, protections and responsibilities of parties to a civil union

The law of domestic relations, including annulment, separation and divorce, child custody and support, and property division and maintenance shall apply to parties to a civil union.

VT ST T. $15 \S 1205$ Modification of civil union terms

c VT ST T. $15 \S 1206$ Dissolution of civil unions

The family division of the superior court shall have jurisdiction over all proceedings relating to the dissolution of civil unions. The dissolution of civil unions shall follow the same procedures and be subject to the same substantive rights and obligations that are involved in the dissolution of civil marriage in accordance with chapter 11 of this title, including any residency requirements.

c VT ST T. $15 \S 1207$ Commissioner of health; duties

\section{Virginia}

c VA CONST Art. $1, \S 15-\mathrm{A}$ Marriage

That only a union between one man and one woman may be a marriage valid in or recognized by this Commonwealth and its political subdivisions.

This Commonwealth and its political subdivisions shall not create or recognize a legal status for relationships of unmarried individuals that intends to approximate the design, qualities, significance, or effects of marriage. Nor shall this Commonwealth or its political subdivisions create or recognize another union, partnership, or other legal status to which is assigned the rights, benefits, obligations, qualities, or effects of marriage.

c VA ST § 20-45.2 Marriage between persons of same sex

A marriage between persons of the same sex is prohibited. Any marriage entered into by persons of the same sex in another state or jurisdiction shall be void in all respects in Virginia and any contractual rights created by such marriage shall be void and unenforceable. 
c VA ST \& 20-45.3 Civil unions between persons of same sex

A civil union, partnership contract or other arrangement between persons of the same sex purporting to bestow the privileges or obligations of marriage is prohibited. Any such civil union, partnership contract or other arrangement entered into by persons of the same sex in another state or jurisdiction shall be void in all respects in Virginia and any contractual rights created thereby shall be void and unenforceable.

\section{Washington \\ PWA ST 26.04.010 Marriage contract--Void marriages}

(1) Marriage is a civil contract between a male and a female who have each attained the age of eighteen years, and who are otherwise capable.

(2) Every marriage entered into in which either the husband or the wife has not attained the age of seventeen years is void except where this section has been waived by a superior court judge of the county in which one of the parties resides on a showing of necessity.

\section{PWA ST 26.04.020 Prohibited marriages}

(1) Marriages in the following cases are prohibited:

(a) When either party thereto has a wife or husband living at the time of such marriage;

(b) When the husband and wife are nearer of kin to each other than second cousins, whether of the whole or half blood computing by the rules of the civil law; or

(c) When the parties are persons other than a male and a female.

(2) It is unlawful for any man to marry his father's sister, mother's sister, daughter, sister, son's daughter, daughter's daughter, brother's daughter or sister's daughter; it is unlawful for any woman to marry her father's brother, mother's brother, son, brother, son's son, daughter's son, brother's son or sister's son.

(3) A marriage between two persons that is recognized as valid in another jurisdiction is valid in this state only if the marriage is not prohibited or made unlawful under subsection (1)(a), (1)(c), or (2) of this section.

\section{West Virginia}

c WV ST § 48-2-104 Contents of the application for a marriage license 
(a) The application for a marriage license must contain a statement of the full names of both female and male parties, their social security account numbers, dates of birth, places of birth and residence addresses.

(b) If either of the parties is a legal alien in the United States of America and has no social security account number, a tourist or visitor visa number or number equivalent to a United States social security account number must be provided.

(c) Every application for a marriage license must contain the following statement: "Marriage is designed to be a loving and lifelong union between a woman and a man. The laws of this state affirm your right to enter into this marriage and to live within the marriage free from violence and abuse. Neither of you is the property of the other. Physical abuse, sexual abuse, battery and assault of a spouse or other family member, and other provisions of the criminal laws of this state are applicable to spouses and other family members, and these violations are punishable by law."

\section{WV ST § 48-2-401 Persons authorized to perform marriages}

A religious representative who has complied with the provisions of section 2-402, a family court judge, a circuit judge or a justice of the supreme court of appeals, is authorized to celebrate the rites of marriage in any county of this state. Celebration or solemnization of a marriage means the performance of the formal act or ceremony by which a man and woman contract marriage and assume the status of husband and wife.

C WV ST § 48-2-603 Certain acts, records, and proceedings not to be given effect in this state

A public act, record or judicial proceeding of any other state, territory, possession or tribe respecting a relationship between persons of the same sex that is treated as a marriage under the laws of the other state, territory, possession, or tribe, or a right or claim arising from such relationship, shall not be given effect by this state.

\section{Wisconsin}

c WI CONST Art. 13, $\$ 13$ Marriage between one man and one woman

Only a marriage between one man and one woman shall be valid or recognized as a marriage in this state. A legal status identical or substantially similar to that of marriage for unmarried individuals shall not be valid or recognized in this state.

\section{WI ST 765.01 A civil contract}

Marriage, so far as its validity at law is concerned, is a civil contract, to which the consent of the parties capable in law of contracting is essential, and which creates the legal status of husband and wife.

WI ST 765.04 Marriage abroad to circumvent the laws

(1) If any person residing and intending to continue to reside in this state who is disabled or prohibited from contracting marriage under the laws of this state goes into another 
state or country and there contracts a marriage prohibited or declared void under the laws of this state, such marriage shall be void for all purposes in this state with the same effect as though it had been entered into in this state.

(2) Proof that a person contracting a marriage in another jurisdiction was (a) domiciled in this state within 12 months prior to the marriage, and resumed residence in this state within 18 months after the date of departure therefrom, or (b) at all times after departure from this state, and until returning maintained a place of residence within this state, shall be prima facie evidence that at the time such marriage was contracted the person resided and intended to continue to reside in this state.

(3) No marriage shall be contracted in this state by a party residing and intending to continue to reside in another state or jurisdiction, if such marriage would be void if contracted in such other state or jurisdiction and every marriage celebrated in this state in violation of this provision shall be null and void.

\section{Wyoming}

P WY ST § 20-1-101 Marriage a civil contract

Marriage is a civil contract between a male and a female person to which the consent of the parties capable of contracting is essential.

This statute was enacted in 1977, pre-DoMA

\section{PWY ST § 20-1-111 Foreign marriages}

All marriage contracts which are valid by the laws of the country in which contracted are valid in this state.

Note: This conflicts with $\$ 20-1-101$

\section{United States}

P 1 U.S.C.A. $\$ 7$ Definition of "marriage" and "spouse"

In determining the meaning of any Act of Congress, or of any ruling, regulation, or interpretation of the various administrative bureaus and agencies of the United States, the word "marriage" means only a legal union between one man and one woman as husband and wife, and the word "spouse" refers only to a person of the opposite sex who is a husband or a wife.

Held Unconstitutional by:

Massachusetts v. U.S. Dept. of Health and Human Services, 698 F.Supp.2d 234 (D. Mass. 2010); Gill v. Office of Personnel Management, 699 F.Supp.2d 374 (D. Mass. 2010).

P28 U.S.C.A. $\$ 1738$ C Certain acts, records, and proceedings and effect thereof 
No State, territory, or possession of the United States, or Indian tribe, shall be required to give effect to any public act, record, or judicial proceeding of any other State, territory, possession, or tribe respecting a relationship between persons of the same sex that is treated as a marriage under the laws of such other State, territory, possession, or tribe, or a right or claim arising from such relationship.

\section{Guam - No DoMA}

19 G.C.A. § 3107 Marriages Outside of Guam

\section{Puerto Rico}

31 L.P.R.A. § 221 Definition, validity, and dissolution of marriage

Marriage is a civil institution, originating in a civil contract whereby a man and a woman mutually agree to become husband and wife and to discharge toward each other the duties imposed by law. It is valid only when contracted and solemnized in accordance with the provisions of law, and it may be dissolved before the death of either spouse only in the cases expressly provided for in this title. Any marriage between persons of the same sex or transsexuals contracted in other jurisdictions shall not be valid or given juridical recognition

in

Puerto

Rico.

\section{Virgin Islands - No DoMA}

c 16 V.I.C. $\$ 31$ Nature of marriage

\section{SUMMARY OF GRANTING/NON-GRANTING STATES}

Issues marriage licenses to same-sex couples: Massachusetts, Connecticut, California*, Iowa, Vermont, New Hampshire, New York and the District of Columbia

Recognizes same-sex marriages from other states: New York, Maryland

Allows civil unions, providing state-level spousal rights to same-sex couples: Delaware, Hawaii, Illinois, New Jersey, Rhode Island (Note: In Connecticut, Vermont and New Hampshire, same-sex marriage has replaced civil unions.)

Grants nearly all state-level spousal rights to unmarried couples (domestic partnerships): California, Oregon, Nevada, Washington

Provides some state-level spousal rights to unmarried couples (domestic partnerships): Hawaii, Maine, Wisconsin and the District of Columbia

* The California Supreme Court ruled on May 15, 2008, that same-sex couples have the right to marry in California. Proposition 8, which amended the California Constitution to define marriage as between one man and one woman, was passed on Nov. 4, 2008. On Aug. 4, 2010, a federal district judge ruled that the same-sex marriage ban in Proposition 8 violated the equal protection 
provisions of the U.S. Constitution. Enforcement of that decision has been stayed pending appeal. California does not currently allow same-sex marriages to be performed. Same-sex marriages performed before Proposition 8 was passed remain valid.

National Conference of State Legislatures, http://www.ncsl.org/issues-research/humanservices/same-sex-marriage.aspx (last visited, Jan. 31, 2012). 